\section{RSP}

http://www.rsp.fsp.usp.br/
Revista de Saúde Pública

\title{
The genesis of the AIDS policy and AIDS Space in Brazil (1981-1989)
}

\author{
Sandra Garrido de Barros', Ligia Maria Vieira-da-Silva" \\ Programa Integrado de Pesquisa em Política, Gestão e Avaliação. Instituto de Saúde Coletiva. Universidade \\ Federal da Bahia. Salvador, BA, Brasil \\ " Programa de Pós-Graduação em Saúde Coletiva. Instituto de Saúde Coletiva. Universidade Federal da Bahia. \\ Salvador, BA, Brasil
}

\section{ABSTRACT}

OBJECTIVE: To analyze the genesis of the policy for controlling AIDS in Brazil.

METHODS: Socio-historical study (1981-1989), based on Bordieu's genetic sociology, by document analysis, bibliographical review, and in-depth interviews. It consisted of a connection between the analysis of the paths of 33 agents involved in the creation of a social space focusing on AIDS-related issues and the historical possibility conditions of the drafting of a specific policy.

RESULTS: AIDS Space is a gathering point for the paths of agents from several social fields (medical, scientific, political, and bureaucratic fields). A specific space for relationships, which enabled the drafting of a policy for controlling the AIDS epidemic, but also a place where the authority to talk about the meaning of the disease, the methods to prevent and treat it was under dispute. The analysis showed how the various structures (democratic administrations in Sao Paulo and at the national level, with public health officers taking important positions) and the lack of a specific therapy contributed to social agents of different ranks and backgrounds to initially set prevention as a priority.

CONCLUSIONS: The rise of the sanitary movement, the organization of SUS, and the dominance of the medical field at the AIDS Space contributed to foster treatment as a part of the measures to control the epidemic. These conditions allowed drafting a policy based on the integrality of care, by linking prevention and treatment in the following decade, with important participation from state bureaucracy and researchers.

DESCRIPTORS: Acquired Immunodeficiency Syndrome history. Policy Making. Sociology, Medical. Social Determinants of Health. Equity in Health. Bourdieu.

\footnotetext{
Correspondence:

Sandra Garrido de Barros

Departamento de Odontologia

Social e Pediátrica

Faculdade de Odontologia - UFBA

Rua Araújo Pinho, 62 Canela

40110-912 Salvador, BA, Brasil

E-mail: sgb@ufba.br
}

Received: 15 Aug 2014

Approved: 22 Aug 2015

How to cite: Barros SG,

Vieira-da-Silva LM. The genesis of the AIDS policy and AIDS Space in Brazil (1981-1989). Rev Saude Publica. 2016;50:43.

Copyright: This is an open-access article distributed under the terms of the Creative Commons

Attribution License, which permits unrestricted use, distribution, and reproduction in any medium, provided that the original author and source are credited. 
a Guerra MAT. Política de controle da AIDS da Secretaria de Estado da Saúde de São Paulo, no período 1983-1992: a história contada por seus agentes [dissertation]. São Paulo (SP): Faculdade de Medicina da Universidade de São Paulo; 1993.

b França MSJ. Ciências em tempos de AIDS: uma análise da resposta pioneira de São Paulo à epidemia [these]. São Paulo (SP): Pontifícia Universidade Católica de São Paulo; 2008.

c Santos VL. Avaliação do grau de implementação do Programa de DST/AIDS no Distrito Sanitário Especial Indígena de Mato Grosso do Sul - Distrito de Dourados [dissertation]. Rio de Janeiro (RJ): Escola Nacional de Saúde Pública da Fundação Oswaldo Cruz; 2009.

${ }^{d}$ Lima SCVS. Avaliação do processo de implementação da política de controle das DST/AIDS no Maranhão [these]. São Luís (MA): Universidade Federal do Maranhão; 2006.

e Monteiro ALO. A relação Estado e Sociedade Civil no processo de formulação e implementação de políticas públicas: análise do Programa Nacional de DST e AIDS (1980-2006) [dissertation] Brasília (DF): Faculdade de Economia e Administração da Universidade de Brasília; 2006.

${ }^{\mathrm{f}}$ Campos LCM. Estado e terceiro setor na prestação de serviços públicos: o Programa Nacional de DST/AIDS: 1994-2005 [dissertation]. São Paulo (SP): Escola de Administração de Empresas de São Paulo da Fundação Getúlio Vargas; 2005.

s Silva CLC. Ativismo, ajuda mútua e assistência: a atuação das organizações não-governamentais na luta contra a aids [these]. Rio de Janeiro (RJ): Universidade Federal do Rio de Janeiro; 1999.

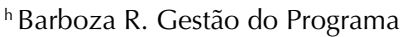
Estadual DST/AIDS de São Paulo: uma análise do processo de descentralização das ações no período de 1994 a 2003 [dissertation]. São Paulo (SP): Coordenadoria de Controle de Doenças da Secretaria de Estado da Saúde de São Paulo; 2006.

iStanise VL. Avaliação do grau de institucionalização dos programas municipais de DST/HIV/AIDS na Regional de Saúde de Campinas, São Paulo, Brasil [dissertation]. Rio de Janeiro (RJ): Escola Nacional de Saúde Pública da Fundação Oswaldo Cruz; 2008.

jBarros SG. A política nacional de luta contra a aids e o espaço aids no Brasil [these]. Salvador (BA): Instituto de Saúde Coletiva da Universidade Federal da Bahia; 2013.

\section{INTRODUCTION}

To analyze the genesis of a public health care policy is to seek to understand the historical and social circumstances that enabled the State to intervene to implement specific measures for controlling a certain health problem ${ }^{22}$.

The studies on the origins of Brazil's AIDS policy, which were reviewed, focused on analyses of state cases, especially Sao Paulo a,b,c,d or on the relationships between non-government organizations (NGO) and the State ${ }^{11, \mathrm{e}, \mathrm{fg}, \mathrm{g}}$, whether by highlighting the political focus of these organizations or by emphasizing the drafting and implementation of the policy for specific groups ${ }^{10}$ at the different levels of the health care system ${ }^{\text {h,i }}$. Those who analyzed the government response to the epidemic at the national level have not investigated the participation of medical and scientific fields, nor have they considered the social and professional paths of agents ${ }^{13,15,18}$.

By putting the concept of social space developed by Bourdieu ${ }^{5}$ into practice, Pinell et al. ${ }^{22}$ studied the universe of possibilities for the rise of a movement to fight AIDS in France, its structure, and its dynamics of relationships of AIDS Space agents between 1981 and 1996. This space was created in that country through a popular mobilization that aimed to replace state institutions in the performance of this public role. The policy against AIDS was drafted by the initiatives of militant associations, the advancements in the medical field, and the illness social representation as a threat to French society.

The study by Mendonça et al. ${ }^{17}$, based on Bordieu's field concept, connected the position at the "HIV/AIDS field" with entrepreneurial action methods. Their analysis focused on the medical field and on specific associations, but did not explore the interaction between the paths of agents and conditions of possibility. The development of a space for fighting AIDS is understood to depend on the medical knowledge on the disease, but not to fulfill all the requirements of a field, as proposed by Bordieu. The concept of AIDS Space as suggested by Pinell et al. ${ }^{22}$ is more appropriate because it is a space of relationships among the agents in different social fields.

The studies reviewed do not shed light on how the AIDS Space was organized in Brazil (composition, agents, disputes, interests) nor do they explain why a policy was drafted at a time when there was no evidence on its extent and vulnerability. Neither have they systematically analyzed the liaisons between agents, the points of view or strategies they chose regarding the policy on AIDS, concerning their fields of origin.

This study on the genesis of Brazil's AIDS policy provides elements that help fill these gaps, based on Bourdieu's reflexive sociology ${ }^{3-8}$.

\section{METHODS}

A socio-historical study was conducted between 1981 and 1989, the time when the AIDS policy had its genesis. This period was defined according to a broader research periodization comprising the interval between 1981 and 2001', considering the main groups affected, times, and priority actions of the government response and its relationship with medical knowledge (Table 1).

The concept of social space is based on the idea of difference: agents are distributed in it according to the various kinds of capital ${ }^{5}$ (Table 2). In turn, the concept of field corresponds to a network of relationships, a relatively autonomous microcosm comprising agents and institutions that have habitus, common perception and action schemes, and illusio, a shared interest ${ }^{4,7}$. The AIDS Space was operationalized as a space of relationships between agents in several fields, with common interest in a problem: IIDS $^{22}$. To rebuild the dynamics of this space and its connections with the medical field, the Collective Health Space ${ }^{25, \mathrm{k}}$ and the political field, we analyzed the social and professional trajectories of 33 agents (in-depth 
Table 1. Times of the national policy on AIDS control, main groups affected, priority initiatives and their relationship with medical knowledge, 1981-2001.

\begin{tabular}{|c|c|c|c|c|}
\hline Period & Main groups affected ${ }^{a}$ & Medical knowledge & Policy on AIDS & Priority initiatives \\
\hline 1981-1984 & Homosexuals & $\begin{array}{l}\text { Discovery of the virus } \\
\text { Blood test }\end{array}$ & $\begin{array}{c}\text { The federal government } \\
\text { does not have a specific } \\
\text { policy }\end{array}$ & State initiatives \\
\hline 1985-1989 & $\begin{array}{l}\text { Homosexuals, people with } \\
\text { hemophilia, and other } \\
\text { recipients of blood and } \\
\text { blood products }\end{array}$ & AZT & $\begin{array}{l}\text { Creation of a national } \\
\text { policy }\end{array}$ & $\begin{array}{l}\text { Health surveillance and } \\
\text { education initiatives }\end{array}$ \\
\hline 1990-1996 & $\begin{array}{l}\text { Injection drug users, } \\
\text { heterosexuals }\end{array}$ & $\begin{array}{c}\text { Conduction of trials for } \\
\text { vaccine studies in Brazil } \\
\text { Combined therapy } \\
\text { (disease control, increased } \\
\text { survival) }\end{array}$ & $\begin{array}{l}\text { Consolidation of the } \\
\text { national policy }\end{array}$ & $\begin{array}{l}\text { Distribution of } \\
\text { medications, } \\
1^{\text {st }} \text { loan agreement, } \\
\text { funding of NGO }\end{array}$ \\
\hline 1997-2001 & $\begin{array}{l}\text { Feminization }^{b} \\
\text { Aging } \\
\text { Interiorization } \\
\text { Impoverishment } \\
\text { Increased survival }\end{array}$ & $\begin{array}{c}\text { New medications } \\
\text { (protease inhibitors), } \\
\text { reduced collateral effects, } \\
\text { disease control }\end{array}$ & $\begin{array}{l}\text { Apex of the national } \\
\text { policy: reduction of } \\
\text { morbidity and mortality } \\
\text { indicators (stabilized } \\
\text { epidemic) and } \\
\text { international recognition }\end{array}$ & $\begin{array}{l}\text { Sustainability of the } \\
\text { universal access strategy }\end{array}$ \\
\hline
\end{tabular}

AZT: azithromycin; NGO: non-government organizations

a Source: Epidemiological AIDS Bulletins, Ministry of Health.

${ }^{\mathrm{b}}$ The ratio between genders between 1980 and 1990 was 6.5:1, and in the period between 1991 and 2001 it was 2.4:1.

${ }^{k}$ Collective Health, in its genesis, according to the findings from an empirical study conducted by Vieira-da-Silva and Pinell ${ }^{25}$ (2013), analyzing the paths of 26 founders, could be interpreted as a social space that aimed to become a field but still did not have relative autonomy or a common habitus, found in consolidated fields, such as scientific, medical, bureaucratic, and political fields.

' Silva LL. Homossexualidade e aids em São Paulo [dissertation]. São Paulo (SP): Pontifícia Universidade Católica de São Paulo; 1986. interviews) (Table 3) and the historical conditions for the rise of the policy (document and bibliographical sources).

The sample was delimited through the saturation of oral information, which were confirmed and complemented by document analysis. The classification of the agents according to their social fields was conducted according to volume indicators of scientific, bureaucratic, militant, and political capital, as proposed by Vieira-da-Silva and Pinell ${ }^{25}$ (Table 4).

The project was approved by the Universidade Federal da Bahia's Collective Health Institute's Research Ethics Committee. The interviewed subjects signed informed consent forms and agreed to have their names disclosed.

\section{RESULTS AND DISCUSSION}

\section{The Construction of the AIDS Space (1981-1984)}

The epidemics arrived in Brazil in the early 1980s, when AIDS was not widely known and no efficient therapeutic response existed. From a political point of view, it was a period marked by the transition to democracy after the military dictatorship that started in 1964.

The first news reports about the disease were treated as a foreign problem by the media ${ }^{2}$ and contributed to it being seen as a gay disease, the so-called "gay plague". The first cases, which were concentrated in Sao Paulo, were identified between 1982 and 1983, by dermatologist Valéria Petri. The patients had Kaposi's sarcoma, which is very unusual in young people. No blood tests existed; diagnose was clinical and therefore questioned by some physicans, according to the interviewed testimonial, "[...] some colleagues insisted I was lying" (E31, 6/20/2011). Despite the role of the press in giving the first reports on AIDS, only in 1983 were the first Brazilian cases reported ${ }^{1,2}$.

Despite first denying the disease, the gay movement was fundamental to recognize AIDS as a problem that required specific measures. The questioning stance on medical field was a result from the historical relationship of some physicians with homosexuality, who viewed it as a mental illness. 
Table 2. Definition of the different kinds of capital.

\begin{tabular}{|c|c|c|}
\hline Type of capital & Description & Source \\
\hline Cultural & $\begin{array}{l}\text { Set of assets related to incorporated knowledge (being competent in a knowledge } \\
\text { domain, being cultured, have a good mastery on language), owning cultural assets } \\
\text { (books, dictionaries, instruments, machines) and, in its institutionalized state, to } \\
\text { degrees, diplomas, and being approved in professional admission tests, that is, to the } \\
\text { recognition of skills by the State. }\end{array}$ & Bourdieu $^{7}$ (2008) \\
\hline Social & $\begin{array}{l}\text { Capital of relationships, regarding the gains associated with the existence of a network } \\
\text { of real or potential connections, more or less institutionalized, of belonging to a group. }\end{array}$ & Bourdieu $^{3}$ (1980) \\
\hline Symbolic & $\begin{array}{l}\text { Transmutation of the various species of capital into recognition capital by the agents in } \\
\text { the social space }\end{array}$ & Bourdieu $^{5}$ (1996) \\
\hline Political & $\begin{array}{l}\text { Related to the mobilization ability of an agent, it is a species of personally-obtained } \\
\text { social and symbolic capital, which results from personal notoriety and popularity } \\
\text { capital (being known and recognized), or by the delegation of an organization that } \\
\text { holds this kind of capital, such as parties or sindicates. It can be achieved through the } \\
\text { access to traditional political positions (positions in a party, in branches of power, in the } \\
\text { network of companies related to parties, or by taking elective offices). }\end{array}$ & $\begin{array}{l}\text { Bourdieu }^{6}(2001) \\
\text { Matonti and Poupeau } \\
\text { (2004) }\end{array}$ \\
\hline Militant & $\begin{array}{l}\text { Set of knowledge and practices implemented in collective initiatives and struggles } \\
\text { between or within parties; it is incorporated through techniques and dispositions to act, } \\
\text { intervene, or simply obey. Under certain conditions, it can be a path to political capital } \\
\text { when, for example, an agent is associated with the personification and disclosure of } \\
\text { an initiative that allows them to convert their acquired militant notoriety into more } \\
\text { institutionalized political investments, such as political parties. }\end{array}$ & $\begin{array}{l}\text { Matonti and Poupeau } \\
\text { (2004) } \\
\text { Garcia }^{12}(2005)\end{array}$ \\
\hline Bureaucratic & $\begin{array}{l}\text { A capital that has power over other kinds of capital, it also corresponds to the power } \\
\text { of nomination, controlling information and standardization, and also defining and } \\
\text { imposing legitimate state categories. }\end{array}$ & Bourdieu $^{8}$ (2012) \\
\hline
\end{tabular}

"[...] Militants tended to think that it was another lie from physicans [...]. Yet another way to control homosexuality, to get people to quit these behaviors" (E8, 5/16/2011).

Afterwards, this group started reinforcing medical discourse, probably as a result from the exchange with foreign groups who brought reports of fear and death, and also because of the threat to the developing gay trade $\mathrm{e}^{14,21, \mathrm{~m}}$.

“[...] I spent a week in New York. [...] I heard about people dying like flies. [...] almost no one believed it" (E8, 5/16/2011).

The epidemic transformed the gay rights movement, by causing its sexual freedom proposals to lose momentum and reducing the number of groups 9 .

Besides diagnosing the first cases, physicians from different backgrounds took part in the initiatives that resulted in the first measures for control of the disease. Ricardo Veronesi (professor at Faculdade de Medicina of the Universidade de Sao Paulo, founder of the Brazilian Society of Infectious Diseases, and responsible for administering interferon as a treatment for AIDS in Brazil), ${ }^{\mathrm{n}, \mathrm{o}}$ gathered gay activists in March 1983, warning them about the need for a response from the government.

"[...] From then on, they started getting organized [...] to try to ensure some achievements, and, at the same time, discuss the AIDS issue and push authorities" (E8, 5/16/2011).

m Silva LL. Homossexualidade e aids em São Paulo [dissertation]. São Paulo (SP): Pontifícia Universidade Católica de São Paulo; 1986

${ }^{\mathrm{n}}$ Interferon teve seus poderes superestimados. Folha de São Paulo. 4 jun 1983.

${ }^{\circ}$ Congresso termina com crítica de médico ao Inamps. Folha de São Paulo. 6 jun 1983.
Motivated by the meeting and by the first AIDS cases in Brazil, Darcy Penteado scheduled an appointment with Sao Paulo’s Health Care Officer, João Yunes ${ }^{15,24}$.

"[...] a demand that had been started by people that had already [...] taken part in the gay rights movement. [...] and demanded the [State Health] Secretariat [...] take measures, provide guidance, give information regarding the epidemic [...]" (E26, 5/3/2011)

Former members of Grupo Somos and of the "Lampião da Esquina" newspaper, such as anthropologist Edward MacRae, Belgian filmmaker Jean Claude Bernadet, writer and journalist 
Table 3. Profile of the subjects interviewed, according to college diplomas, year when joined AIDS Space, insertion sub-space, volume of scientific, bureaucratic, political, and militant capital, relationship with AIDS, and presence at AIDS Space during the rise of the national policy for controlling the epidemic, 1985

\begin{tabular}{|c|c|c|c|c|c|c|c|c|c|c|}
\hline \multirow{2}{*}{$\mathbf{E}$} & \multirow{2}{*}{$\begin{array}{l}\text { Undergraduate diploma } \\
\text { (institution, year) }\end{array}$} & \multirow{2}{*}{$\begin{array}{l}\text { Year when } \\
\text { joined the } \\
\text { space }\end{array}$} & \multirow{2}{*}{ Sub-space } & \multicolumn{5}{|c|}{ Volume of capital (1983-1986) } & \multirow{2}{*}{$\begin{array}{l}\text { Relationship } \\
\text { with AIDS }\end{array}$} & \multirow{2}{*}{$\begin{array}{l}\text { Rise of } \\
\text { PNAids } \\
\text { (1985) }\end{array}$} \\
\hline & & & & Cultural & Scientific & Bureaucratic & Political & Militant & & \\
\hline 1 & Social sciences (PUC-SP, 1992) & 1983 & Bureaucratic & $\mathrm{HC}$ & - & - & - & - & Professional & $x$ \\
\hline 2 & Medicine (UFBA) & 1993 & & - & - & - & - & - & Professional & - \\
\hline 3 & Law (PUC-SP, N/I) & 1983 & Militant & $\mathrm{CHE}$ & - & - & B & B & $\begin{array}{l}\text { Professional/ } \\
\text { Personal }\end{array}$ & $x$ \\
\hline 4 & Medicine (UFBA, 1969) & 1983 & Scientific & G & $\mathrm{AA}$ & B & B & - & Professional & $x$ \\
\hline 5 & Social sciences (UFRJ, 1988) & 1989 & Militant & - & - & - & - & - & Professional & - \\
\hline 6 & Philosophy (Unesp, N/I) & 1994 & Militant & - & - & - & - & - & $\begin{array}{l}\text { Personal } \\
\text { HIV+ }\end{array}$ & - \\
\hline 7 & Medicine (UFRJ, 197?) & 1983 & Scientific & $\mathrm{CHE}$ & - & - & - & - & Professional & - \\
\hline 8 & Social Psychology (US, 1968) & 1983 & Militant & G & M & - & - & B & Political & $x$ \\
\hline 9 & Medicine (UFBA, 1965) & 1985 & Scientific & G & A & - & - & - & Research & $x$ \\
\hline 10 & Medicine (UFBA, 1968) & 1985 & Bureaucratic & G & B & AA & B & - & Professional & $x$ \\
\hline 11 & Medicine (UFPI, 1983) & 1986 & Bureaucratic & $\mathrm{CHE}$ & - & A & - & - & $\begin{array}{l}\text { Professional/ } \\
\text { Personal }\end{array}$ & $X$ \\
\hline 12 & $\begin{array}{l}\text { Business Administration } \\
\text { (Methodist University } \\
\text { Center - SP, after 2001) }\end{array}$ & 1986 & Militant & - & - & - & - & - & $\begin{array}{l}\text { Personal } \\
\text { HIV+ }\end{array}$ & - \\
\hline 13 & $\begin{array}{l}\text { Hospitality (Renascença } \\
\text { Hebrew School, 1994) }\end{array}$ & 1994 & Militant & - & - & - & - & - & $\begin{array}{l}\text { Personal } \\
\text { HIV+ }\end{array}$ & - \\
\hline 14 & $\begin{array}{l}\text { Business Administration } \\
\text { (UCSal, after 2001) }\end{array}$ & 1987 & Militant & - & - & - & - & & - & - \\
\hline 15 & Tourism (N/I) & 1986 & Bureaucratic & $\mathrm{CHE}$ & - & B & - & - & Professional & - \\
\hline 16 & Medicine (EBMSP, 1981) & 1990 & Scientific & - & - & - & - & - & Professional & - \\
\hline 17 & $\begin{array}{l}\text { Sociology (Sao Paulo School of } \\
\text { Political Sociology, N/I) }\end{array}$ & 1992 & Bureaucratic & - & - & - & - & - & Professional & - \\
\hline 18 & Mathematics (UBA, 1972) & 1986 & Militant & G & M & - & B & A & $\begin{array}{l}\text { Personal } \\
\text { HIV+ }\end{array}$ & - \\
\hline 19 & Medicine (USP, 1961) & 1983 & Scientific & G & A & A & B & - & Professional & $x$ \\
\hline 20 & Social Sciences (USP, 1968) & 1983 & Militant & G & M & - & B & A & Political & $x$ \\
\hline 21 & Economics (UnB, after 2001) & 1986 & Bureaucratic & ES & - & - & - & - & Professional & - \\
\hline 22 & Psychology (UFBA, 1991) & 1987 & Militant & - & - & - & - & - & Personal & - \\
\hline 23 & Medicine (UFBA, 1989) & 1990 & Bureaucratic & - & - & - & - & - & - & - \\
\hline 24 & Medicine (EMESCAM, 1975)* & 1985 & Bureaucratic & $\mathrm{CHE}$ & - & A & - & B & Professional & $x$ \\
\hline 25 & Social Sciences (Unesp, 1987) & 1988 & Scientific & - & - & - & - & - & - & - \\
\hline 26 & Medicine (Unesp, 1973) & 1983 & Bureaucratic & $\mathrm{CHE}$ & - & A & - & B & Professional & $x$ \\
\hline 27 & Medicine (UFRJ, 1986) & 1986 & Bureaucratic & $\mathrm{CHE}$ & - & A & - & - & Professional & - \\
\hline 28 & Data processing technologist (N/I) & 1993 & Bureaucratic & - & - & - & - & - & Professional & - \\
\hline 29 & Psychology (PUC-RJ, 1978) & 1986 & Militant & G & B & - & B & A & Professional & - \\
\hline 30 & Medicine (UERJ, 1985) & 1986 & Scientific & $\mathrm{CHE}$ & - & - & - & - & Professional & - \\
\hline 31 & Medicine (Unifesp, 1973) & 1983 & Scientific & G & M & - & - & - & Professional & $x$ \\
\hline 32 & Psychology (USP, 1977) & 1984 & Scientific & - & - & - & - & - & Professional & $x$ \\
\hline 33 & Psychology (UERJ, 1985) & 1985 & Militant & G & $\mathrm{P}$ & - & $\mathrm{P}$ & A & Political & $x$ \\
\hline
\end{tabular}

E: subject interviewed; PUC-SP: Pontifícia Universidade Católica de São Paulo; UFBA: Universidade Federal da Bahia; N/I: no information; UFRJ: Universidade Federal do Rio de Janeiro; Unesp: Universidade Estadual Paulista "Júlio de Mesquita Filho"; US: University of Sussex; UFPI: Universidade Federal do Piauí; UCSal: Universidade Católica de Salvador; EBMSP: Escola Bahiana de Medicina e Saúde Pública; UBA: Universidad de Buenos Aires; USP: Universidade de São Paulo; UnB: Universidade de Brasília; EMESCAM: Escola Superior de Ciências da Santa Casa de Misericórdia de Vitória; PUC-RJ: Pontifícia Universidade Católica do Rio de Janeiro; UERJ: Universidade do Estado do Rio de Janeiro; UNIFESP: Universidade Federal de São Paulo; HC: high school; CHE: complete higher education; G: graduate; ES: elementary school; AA: very high scientific capital volume; M: medium scientific capital volume; A: high scientific capital volume; B: low scientific capital volume; PNAids: Brazil's National Policy on AIDS

* E-mail contact 
Table 4. Criteria for analyzing the composition of different species of capital during the rise of AIDS Space in Brazil, 1981-1986.

\begin{tabular}{|c|c|c|c|c|}
\hline Volume of capital & Very high (HH) & High (H) & Medium (M) & Low (L) \\
\hline \multicolumn{5}{|l|}{ Type of capital } \\
\hline \multicolumn{5}{|l|}{ Scientific } \\
\hline & $\begin{array}{l}\text { International } \\
\text { recognition }\end{array}$ & $\begin{array}{l}\text { National } \\
\text { recognition }\end{array}$ & $\begin{array}{l}\text { Local } \\
\text { recognition }\end{array}$ & $\begin{array}{l}\text { Master's } \\
\text { degree }\end{array}$ \\
\hline & International awards & Full professor & $\begin{array}{l}\text { Physican's } \\
\text { degree }\end{array}$ & - \\
\hline & $\begin{array}{c}\text { Coordinating research } \\
\text { or structuring projects } \\
\text { funded by international } \\
\text { agencies }\end{array}$ & $\begin{array}{l}\text { Coordinating } \\
\text { projects funded } \\
\text { by national } \\
\text { agencies }\end{array}$ & $\begin{array}{l}\text { Taking part in } \\
\text { research projects } \\
\text { related to the } \\
\text { response to the } \\
\text { epidemic }\end{array}$ & - \\
\hline \multicolumn{5}{|l|}{ Bureaucratic $^{b}$} \\
\hline $\begin{array}{l}\text { Occupying } \\
\text { technical positions }\end{array}$ & $\begin{array}{l}\text { Management positions } \\
\text { in international } \\
\text { agencies (UNAids, } \\
\text { PAHO, WHO) } \\
\text { Managers in the National } \\
\text { STD/AIDS Program or } \\
\text { higher positions with } \\
\text { power of interfering in } \\
\text { the AIDS policy }\end{array}$ & $\begin{array}{l}\text { Management of } \\
\text { state programs } \\
\text { Technicians in } \\
\text { the National } \\
\text { STD/AIDS } \\
\text { Program } \\
\text { Participation } \\
\text { in meetings for } \\
\text { defining the } \\
\text { MH's policy }\end{array}$ & $\begin{array}{l}\text { Intermediate } \\
\text { management } \\
\text { positions in } \\
\text { municipal health } \\
\text { care offices } \\
\text { (municipal } \\
\text { programs) } \\
\text { Technicians in } \\
\text { state programs }\end{array}$ & $\begin{array}{c}\text { Technical } \\
\text { positions } \\
\text { (advisor, } \\
\text { consultant) }\end{array}$ \\
\hline \multicolumn{5}{|l|}{ Political } \\
\hline $\begin{array}{l}\text { Occupying } \\
\text { administrative } \\
\text { positions that result } \\
\text { in specifically } \\
\text { political liaison }\end{array}$ & $\begin{array}{l}\text { Health minister, agency } \\
\text { presidents }\end{array}$ & $\begin{array}{l}\text { State health } \\
\text { secretary }\end{array}$ & $\begin{array}{l}\text { Municipal health } \\
\text { secretary }\end{array}$ & $\begin{array}{l}\text { Other } \\
\text { politically- } \\
\text { appointed } \\
\text { technical } \\
\text { positions }\end{array}$ \\
\hline $\begin{array}{l}\text { Participation in } \\
\text { political parties }\end{array}$ & National manager & $\begin{array}{l}\text { State manager of } \\
\text { a political party }\end{array}$ & $\begin{array}{c}\text { Municipal } \\
\text { manager of } \\
\text { political parties }\end{array}$ & $\begin{array}{l}\text { Member of } \\
\text { a political } \\
\text { party }\end{array}$ \\
\hline $\begin{array}{l}\text { Participation in } \\
\text { elective offices }\end{array}$ & Senator, congressman & Assemblyman & Alderman & - \\
\hline \multicolumn{5}{|l|}{ Militant } \\
\hline $\begin{array}{l}\text { Professional and } \\
\text { popular leaders }\end{array}$ & $\begin{array}{l}\text { A charismatic leader } \\
\text { who is capable of } \\
\text { mobilizing and } \\
\text { gathering people (high } \\
\text { symbolic capital) }\end{array}$ & $\begin{array}{l}\text { NGO or social } \\
\text { movement } \\
\text { manager }\end{array}$ & $\begin{array}{l}\text { Intermediate } \\
\text { NGO or social } \\
\text { movement staff }\end{array}$ & $\begin{array}{l}\text { NGO or } \\
\text { social } \\
\text { movement } \\
\text { militants }\end{array}$ \\
\hline
\end{tabular}

UNAids: Joint United Nations Program on HIV/AIDS; PAHO: Pan American Health Organization; WHO: World Health Organization; MH: Ministry of Health; NGO: non-government organization ${ }^{a}$ Adapted from Vieira-da-Silva and Pinell ${ }^{22}$.

${ }^{\mathrm{b}}$ Measured based on occupied positions, whereas the technical office occupation requires titles (acquired cultural capital) suitable for the position in question.

João Silvério Trevisan, and physician Valéria Petri (E8, E31), followed Darcy Penteado. They requested that Sao Paulo's State Heath Secretariat (SES-SP) made a statement about AIDS and future cases treatment. This meeting motivated a movement for creating the AIDS Program at SES-SP, at Hansen's Disease and Public Health Dermatology Division, which was coordinated by physician Paulo Roberto Teixeira, a former member of Grupo Somos (E26).

According to other studies ${ }^{15,24}$, the following contributed to the implementation of the AIDS Program at SES-SP: the first cases diagnosed; the demand for a group of militants, with support from a female physican; and the political conditions (democratic government, 
with sanitarians in strategic positions). The fear of the epidemic, the social group affected (an organized, upper class group of intellectuals with an important social capital), and the fact Sao Paulo had had a health care system with public health officer positions as of the 1960s should be added ${ }^{p}$, as well as the profile of the system's director (a sanitarian and former member of the gay rights movement), a person with technical and political capability of dealing with stigmatized groups (E26).

Federal education and research institutions engaged by initiative of their professors and researchers. For example, Escola Paulista de Medicina, by physician Valéria Petri (E31), and Fiocruz, by its AIDS Research Laboratory. The latter was created in 1983, in Rio de Janeiro, by Bernardo Galvão, physician, master in Human Pathology, and $\mathrm{PhD}$ in Immunology, who became its coordinator, and Cláudio Ribeiro, a PhD in Immunohematology (E4).

The rise of Sao Paulo State AIDS Program confirmed the organization of a space to fight AIDS (AIDS Space). It was also a space for research and intervention, involving agents in the gay rights movement (militant space), in the medical field, teaching professionals, and researchers (scientific field), or staff in the state health care office (bureaucratic field).

\section{The Response from the Ministry of Health (1985-1989)}

In February 1985, federal government initiatives for controlling AIDS were initiated through Professional Training for Controlling Hospital-Acquired Infections Program, which was coordinated by Luiz Carlos Pelizari Romero, from the National Secretariat for Special Health Care Programs (SNPES) ${ }^{q}$. Fabíola de Aguiar Nunes, a sanitarian physician, took part in the program as a representative from the Ministry of Education and Culture (E10).

When Carlos Sant'Anna, a physician, congressman, and one of the liaison agents in Tancredo Neves' presidential election run, took over the Ministry of Health (MH) in March 1985, Fabíola Nunes took over SNPES, where, in the National Public Health Dermatology Division (DNDS), Brazil's National Program on Sexually-Transmitted Diseases (STD) and AIDS (PNAids) would be created (E10, E11, E24).

The first measures taken by the MH were epidemiological surveillance, public health education and information, voluntary testing, and characterization of an epidemic that affected the whole population, to reduce stigma and discrimination of the most affected groups (E10, E11, E24).

Several social movements (homosexual, thalassemic, and hemophiliac) demanded a response from the government. The press insisted on the issue (E10, E26). Sao Paulo, Rio de Janeiro, and Rio Grande do Sul had already structured measures (E24), pressing the federal government to make a decision. The social representation of the disease, coupled with terror and fear, should be added to this.

In March 1985, meetings were held in Sao Paulo and Brasilia, to review and discuss the cases diagnosed. These meetings respectively resulted in the standardization of AIDS management procedures and the drafting of an ordinance by a panel of experts ${ }^{\mathrm{r}}$. Epidemiological, clinical, and laboratory investigation were proposed, as well as public health education for suspected and confirmed cases, people in contact, and high-risk groups. The ordinance mentioned using condoms, disposable or individual syringes and needles, and controlling blood quality as preventive measures . A training system was organized in Sao Paulo, for the states reporting their first cases (E10).

In January 1986, Fabíola Nunes invited dermatologist Maria Leide de Oliveira to DNDS (E10, E24). Miriam Franchini was responsible for STDs and sanitarian Lúcia Amaral, for AIDS, organizing an initial reporting system ${ }^{19}$. Lair Guerra de Macedo Rodrigues, a biomedical and professor at Universidade de Brasilia who had taken a specialization course at the Centers for Disease Control and Prevention (CDC) in the USA, was invited by Maria Leide to take over the AIDS program. The motivations behind this invitation were her experience at the 
'Ministério da Saúde, Secretaria de Políticas de Saúde, Coordenação Nacional de DST e AIDS.

Comissão Nacional de AIDS: 1986-1994. Brasília (DF); 1994.

"Médico diz que detentos internados não apresentam sintomas de aids. Folha de São Paulo. 8 out 1986.

v Ministério da Saúde. AIDS e Constituinte: subtema da VIII Conferência Nacional de Saúde. Brasília (DF); 1986.

"Teixeira PR, Oliveira MLWDR, Pluciennik TI, Rosenthal C, Petri V, Koperstych S, et al. Debate AIDS. Interviewer: Rodolfo Gamberini. São Paulo: TV Cultura; 1987. Transcribed interview given to Roda Viva TV show on January 19 , 1987. Available from: http:// www.rodaviva.fapesp.br/ materia/211/entrevistados/ debate_aids_1987.htm

× Pastoral pede clareza na campanha. Folha de São Paulo. 26 fev 1987

y Contrera WF. GAPAs: uma resposta comunitária à epidemia da AIDS no Brasil. Brasília (DF): Ministério da Saúde; 2000.
CDC, her good references, and her potential influence and international support, as Carlyle Guerra de Macedo's, a representative from the Pan American Health Organization (PAHO) was her brother (E24). As Maria Leide joined, a committee on risk group ${ }^{19}$ was created. It was the precursor of Brazil's National Aids Commission (CNAids) (E24) and it played an important technical and political role, by providing guidance to PNAids on the definition of adopted strategiest.

The initiatives aimed at structuring the program and preventing AIDS. The implementation of activities started being centrally managed by the $\mathrm{MH}$, in a way to invert the relationship with the states, which by then created and executed their specific programs ${ }^{24}$.

AIDS was included in Brazil's 8th National Health Conference, within "Epidemiological Surveillance" sub-topic. Later, the MH coordinated debates on "AIDS and Constitutional Convention" topic in the states, and this subsidized the national 1987 campaign, which discussed how the new health care system could solve the AIDS issue ${ }^{\mathrm{u}, \mathrm{v} w}$.

The analysis of documents and interviews showed that Lair Guerra's administration was marked by NGO criticism related to the care of patients, to the campaigns, and to the official discourse, which was considered normative and medicalizing. Criticism was mainly given against 1988's campaign, which held individuals accountable for measures they were not capable of taking, such as controlling their blood quality, in a way to shift responsibility from the state to the people. Nonetheless, there were also people supporting the government campaign (Table 5).

The relationship between the disease, sexuality, and use of injection drugs led its concept to be influenced by the religious discourse. Catholic tradition especially instilled the impression the disease was related to sin, moral transgression, and divine punishment, opposite to the discourse from homosexual groups ${ }^{\mathrm{x}}$. This issue was mentioned by some subjects interviewed, and it shows the importance of analyzing the roles of agents in this field in setting the policy.

When it started being referred to as Acquired Immunodeficiency Syndrome (AIDS) (Sindrome da Imunodeficiência Adquirida - SIDA, in Portuguese), the foreign term was incorporated by physicians and the press in Brazil. Was the incorporation of a foreign word submission from scientific and cultural field agents to the USA, or simply a wish for better international communication in the scientific field? When asked, one of the interviewed subjects shows that, in the $\mathrm{MH}$, its adoption was rationalized and formalized in a meeting for defining the term to be used.

"[...] I was present in the main meeting when they decided Brazil was not going to refer to it as SIDA [...] to keep from stigmatizing all Cidas [short for Aparecida, a common female name in Brazil]. That is why AIDS was chosen" (E11, 8/4/2011).

The associations that fight AIDS (NGO/AIDS), which rose from 1985, had a determining role for regulating the control of blood and blood products ${ }^{23}$ and in the lobby in the constitutional convention for pushing the blood issue $e^{20, y}$.

The empirical material showed that the main disputes between agents in the PNAids and in the association movement revolved around the preventive campaigns (target population, technical or popular language, what could be said, which terms to use, among other things). And from the release of zidovudine (AZT), also regarding treatment.

During the whole period analyzed, the technical conception from the bureaucratic field prevailed in the official discourse. However, due to the influence from militant and religious fields, AIDS was considered to be a threat to society in general rather than restricted to specific groups.

Lair's international negotiations with the $\mathrm{CDC}$ and PAHO, as well as her management ability, contributed to the initial structuring and extension of PNAids. The Program also had important support from the Special Public Health Care Services Foundation for its 
interiorization, through its representative for transmittable diseases, sanitarian physician Pedro Chequer, who later was part of PNAids team ${ }^{19}$.

Getting PNAids attached to DNDS was under dispute, and this resulted from disagreements between agents from the medical field (Fabíola and Maria Leide) and AIDS Space, which was consolidating itself and seeking autonomy (Lair Guerra) (E10). In 1987, after Fabíola Nunes left SNPES, Brazil's National STD/AIDS Division ${ }^{19}$ was created. It was no longer part of DNDS and had autonomy regarding public health dermatology, a medical specialty. Its creation and transference to Brazil's National Office of Basic Health Care Initiatives were made official in 1988. Lair remained in the management of the division until March 1990, during the early Collor administration.

\section{AIDS Space: Its Agents and Sub-spaces}

The following people affected by the epidemic engaged in AIDS Space: HIV positive people, people who were more vulnerable to AIDS (homosexuals, injection drug users, people

Table 5. Some characteristics from the sub-spaces according to interviewed subjects and document analysis.

\begin{tabular}{|c|c|}
\hline Sub-space & Characteristic \\
\hline & $\begin{array}{l}\text { Detachment of NGO/AIDS from the gay rights movement } \\
\text { [...] we founded the Bahia Anti-AIDs Center, [...] to give lectures [...] at schools, universities, syndicates, } \\
\text { neighborhood associations, the phrase gay group still caused prejudice, }[\ldots] \text { it was a way to diversify and } \\
\text { camouflage our actions [...]" (E20 on } 3 / 23 / 2011, \text { Salvador, BA). } \\
\text { "[...] We just try to make it clear this is an anti-AIDS movement, not a gay movement[...]" (E3, on } \\
6 / 20 / 2011 \text {, Sao Paulo, SP). }\end{array}$ \\
\hline & $\begin{array}{l}\text { Funding } \\
\text { "At the time the first here was a fund from INPS, Hésio Cordeiro, [...] destined a share of the funds there to ABIA. } \\
\qquad[\ldots] \text { " (E29, on 6/15/2011, Rio de Janeiro, RJ). } \\
\text { "[...] We set a space aside, as well as rooms and communication equipment: mail, telephone, etc., and this was the } \\
\text { first, let us say, support. [...] Gapa was created inside the institution [SES-SP] [...]" (E26, 5/3/2011, Sao Paulo, SP). }\end{array}$ \\
\hline Militant space & $\begin{array}{l}\text { Main disputes } \\
\text { "Gapa's perspective leaned towards advocacy, ABIA had a concentration, a very high expertise to give } \\
\text { information and guidance to specific groups" (E29, on 6/15/2011, Rio de Janeiro, RJ). } \\
\text { "[...] the king ONGs were Gapa, Pela Vida, ABIA, and the others were all small" (E26, 5/3/2011, Sao Paulo, SP). } \\
\text { "[...] The MSM category does not help anybody, nor does the prevention for bisexual individuals, not even to the } \\
\text { queers and transvestites themselves, who often do not even consider they are men, then we protest against it, } \\
\text { and still nowadays there are people defending it, but it is a misguided way as shown by the experience" (E20, on } \\
\text { 3/23/2011, Salvador, BA). }\end{array}$ \\
\hline
\end{tabular}

Conception regarding government campaigns

$[\ldots]$ there is no real care program to help the sick people. [...] There is no consistent program for education or information. [...] In this campaign, the only information that is really clear is that the government does not know this country, nor the responsibilities it has to it [...]" ABIA Bulletin, no. 2, April 1988).

"[...] even though it is late, shy, and filled with gaps, the government campaign has achieved tangible results in making different social layers aware [...]" (Luiz Mott, GGB, Letter sent to ABIA, ABIA Bulletin, no. 3, July 1988).

"After the Ministry of Health sent me an official passport, [...] so then I could represent Brazil in the United States, they started contradicting me [...]" (E31, 6/20/2011, Sao Paulo, SP).

Scientific field "They did not accept that other agency instead of Fiocruz would do it. [...] I managed to get grants in the United States. UFRJ had an agreement signed with Fiocruz. [...] The Ministry of Health did not give statements approving the project. [...] However, as they were not the ones that would do it, they canceled it. Two and a half

Medical field

Bureaucratic field million dollars" (E7, 6/15/2011, 12/7/2011, and 12/8/2011, Rio de Janeiro, RJ, Skype).
"[...] At that time, they thought a dermatologist could disturb their work or that which they intended to do. So
they said that on television. Once Veronesi said "A dermatologist only serves to disrupt" [...] (E31, 6/20/2011, Sao Paulo, SP).

"[...] all the programs, at a certain point, were organized in public health dermatology offices in the states. Similar to what had happened in Sao Paulo and because of the relationships we had. [...] at that time, the whole public health dermatology department of the Ministry of Health, in 1983, 1984, specially, had a very indecisive stance, even opposing us. [...] that caused a certain agitation in the ministry concerning the topic $[\ldots]^{\prime \prime}($ E26, 5/3/2011, Sao Paulo, SP).

NGO/AIDS: Specific AIDS-related non-government organization; INPS: National Institute of Social Security; ABIA: Brazilian Interdisciplinary AIDS Association; Gapa: Aids Support and Prevention Group; SES-SP Sao Paulo's State Health Secretariat; MSM: Men who have sex with men; GGB: Bahia's Gay Group; FIOCRUZ: Oswaldo Cruz Foundation; UFRJ: Universidade Federal do Rio de Janeiro 
with hemophilia, sex workers); their parents and friends; professionals related to the epidemic, especially physicians and researchers. Those who enter this space for personal reasons, in general, joined the militant sub-space, had diverse educational backgrounds, and important cultural capital, with master's or PhD's degrees. In the bureaucratic and scientific sub-spaces, physicians predominated; the scientific field agents had graduate diplomas or were attending such courses (Table 3).

Despite the importance of the gay movement in planning the first responses to the epidemic, the NGO/AIDS were created seeking get detached from this movement (E3, E20) (Table 5).

The first NGO/AIDS were funded by the State: Aids Support and Prevention Group (Gapa) by SES-SP (E3, E26), and Brazilian Interdisciplinary AIDS Association (ABIA) by the National Social Security Institute of Medical Care (E29) and by Finep ${ }^{20}$, through public health militants taking over positions in these institutions, such as Hésio Cordeiro and Reinaldo Guimarães.

In this sub-space, the main issues were funding, structure, and liaison with the PNAids, living with HIV/AIDS, strategies for prevention and use of the technical formulation "men who have sex with men" (MSM). Disputes were also between the NGO/AIDS and groups in which AIDS was a cross-sectional topic, NGOs with more political perspectives (ABIA) and NGO focusing on care (Gapa) (E3, E12, E14, E18, E20, E29, E33) (Table 5).

In the scientific field, young researchers and new $\mathrm{PhD}$ engaged themselves, seeking independent and original research lines. The main disputes were between generations or institutions. What was at stake was the recognition of the scientific authority or the position of state expert (E4, E7, E31) (Table 5).

In the medical field, the disputes were between dermatologists, infectious disease specialists, tropical medicine, and infectious and parasitic diseases (E4, E31) (Table 5).

In the bureaucratic field, the disputes were between State Health Secretariats and PNAids (E10, E26) (Table 5). Some agents had priority insertion in this field, where agents from the remaining sub-spaces circulated through the CNAids or by taking over positions at PNAids or the remaining management levels.

The meeting of conceptions from the different sub-spaces on AIDS contributed to a broad construction of the problem and actions, based on the dignity of patients and human rights. CNAids, as the State commission that concentrated scientific and militant powers, transmuted into bureaucratic power, had an important role in planning the official discourse, which enabled negotiations between agents from different sub-spaces.

\section{Political and Militant Path}

Some of the agents involved in the genesis of the policy had a dominant political path, by occupying elective offices (Carlos Sant’Anna and Sérgio Arouca). Others had taken part in the sanitary movement (E9, E10, E26, E27), in the gay rights movement (E8, E18, E20, E26, E33), and in the fight against dictatorship, in clandestine parties such as Brazil's Communist Party (E4, E12), and Ação Popular (Popular Action) Party (E26) Most agents who had political capital to some extent stood out in the militant space, taking over dominant positions, such as the management of NGO/AIDS or other associative organizations (Table 3).

\section{Final Considerations}

This socio-historical analysis allowed explaining how the initial demand from militants to SES-SP took place, highlighting the role of the scientific field, from the start of the epidemic. It also recovered the initial formulation of the policy at the national level, which had rarely been described in the literature, identifying the main agents involved and showing the 
implementation of initiatives already in the last months of the military government. It also showed the importance of the participation of sanitarians who took over government positions at that time.

AIDS Space was historically constituted as a space for fighting for the organization of the response to the epidemic and public health care intervention. The authority to talk about the meaning of the disease, the methods to prevent, and treat it were under dispute, as well as strategies for controlling the epidemic. Its structure involved agents from the medical field, from "Collective Health Space", from the bureaucratic field, from the gay rights movement, and from the scientific field, influenced by political, religious, and juridical fields. Later, movements of people with hemophilia, people with thalassemia and sex workers, and NGO/AIDS, composing the militant sub-space.

The government response had the level of government that implemented the first initiatives as a specific aspect. Traditionally, the MH had a national policy, which was followed and enforced by the states. The initiatives against AIDS were started in the states, when $\mathrm{MH}$ denied the need for intervention. The national policy was implemented since 1985. The conditions that enabled including AIDS in the political agenda were the following: the democratic transition process; sanitarians taking over management positions at the $\mathrm{MH}$; the quick spread of the epidemic; the existence of research groups of infectious and parasitic diseases, involving pathologists who became immunologists; the advancements in the medical field regarding the disease, and the development stage of the clinical and laboratory research; the organization of AIDS programs by some states; and the pressure from social movements and the press.

The comprehension of the historical reasons that allowed the initial planning of this policy and the analysis of the paths of agents and struggles common to AIDS Space and to the "Collective Health Space" empirically show the relationship between the policy and the sanitary reform movement and its assumptions. Its origin, during a time when the sanitary reform movement was rising and when there was no specific therapy, contributed to the initial prioritization of prevention. The dominance of the medical field and the constitution of the Brazilian Unified Health System (SUS) contributed to a connection between preventive measures and ensured treatment, a component that is necessary for implementing a policy that is based on integral care, which is internationally considered as an example.

\section{REFERENCES}

1. Abbade ACS, Baião F, organizadores. 100 nomes que fizeram a história da luta contra a AIDS no Brasil. São Paulo (SP): GAPA BR SP; 2010.

2. Barata GF. O Fantástico apresenta a Aids ao público (1983-1992). In: Nascimento DR, Carvalho DM, Marques RC, organizadores. Uma história brasileira das doenças. Rio de Janeiro (RJ): Mauad Editora; 2006. v.2.

3. Bourdieu P. Le capital social: notes provisoires. Actes Rech Sci Soc. 1980;31(1):2-3.

4. Bourdieu P. As regras da arte: gênese e estrutura do campo literário. Lisboa: Editorial Presença; 1996.

5. Bourdieu P. Razões práticas: sobre a teoria da ação. Campinas (SP): Papirus; 1996.

6. Bourdieu P. O poder simbólico. Rio de Janeiro (RJ): Bertrand Brasil; 2001.

7. Bourdieu P. A distinção: crítica social do julgamento. Porto Alegre (RS): Zouk; EDUSP; 2008.

8. Bourdieu P. Sur l'État: cours au Collège de France 1989-1992. Paris: Seuil; 2012.

9. Facchini R. Movimento homossexual no Brasil: recompondo um histórico. Cad AEL. 2003;10(18-19):83-123.

10. Fonseca EM, Nunn A, Souza-Júnior PB, Bastos FI, Ribeiro JM. Descentralização, AIDS e redução de danos: a implementação de políticas públicas no Rio de Janeiro, Brasil. Cad Saude Publica. 2007;23(9):2134-44. DOI:10.1590/S0102-311X2007000900021

11. Galvão J. AIDS no Brasil: a agenda de construção de uma epidemia. São Paulo (SP): Editora 34; 2000. 
12. Garcia S. Expertise scientifique et capital militant: le rôle de médecins dans la lutte pour la légalisation de l'avortement. Actes Rech Sci Soc. 2005;(158):96-115. DOI:10.3917/arss.158.0096

13. Gómez EJ. How Brazil outpaced the United States when it came to AIDS: the politics of civic infiltration, reputation, and strategic internationalization. J Health Polit Policy Law. 2011;36(2):317-52. DOI:10.1215/03616878-1222739

14. MacRae E. A construção da igualdade: identidade sexual e política no Brasil da abertura. Campinas (SP): Editora Unicamp; 1990.

15. Marques MCC. A história de uma epidemia moderna: a emergência política da Aids/HIV no Brasil. Maringá: Editora da Universidade Estadual de Maringá; 2003.

16. Matonti F, Poupeau F. Le capital militant: essai de définition. Actes Rech Sci Soc. 2004;(155):5-11. DOI:10.3917/arss.155.0004

17. Mendonça PME, Alves MA, Campos LC. Empreendedorismo institucional na emergência do campo de políticas públicas em HIV/Aids no Brasil. RAE-electron [Internet]. 2010 [citado 2012 jun 13];9(1). Disponível em: http://dx.doi.org/10.1590/S1676-56482010000100007

18. Nunn A. The politics and history of AIDS treatment in Brazil. New York: Springer Science; 2009.

19. Oliveira MLW. Participação em quatro décadas da política de controle da hanseníase no Brasil: acasos e determinações. Hansenol Int. 2008;33(2 Supl 1):45-50.

20. Parker R Terto Jr V, organizadores. Solidariedade: a ABIA na virada do milênio. Rio de Janeiro (RJ): ABIA; 2001.

21. Perlongher N. O que é AIDS? São Paulo (SP): Brasiliense; 1987.

22. Pinell $P$, Broqua $C$, Busscher $P O$, Jauffret $M$, Thiaudière $C$. Une épidémie politique: la lutte contre le sida en France (1981-1996). Paris: Presses Universitaires de France; 2002.

23. Santos LAC, Moraes C, Coelho VSP. Os anos 80: a politização do sangue. Physis. 1992;2(1):107-49. DOI:10.1590/S0103-73311992000100005

24. Teixeira PR. Políticas públicas em AIDS. In: Parker R, organizador. Políticas, instituições e AIDS: enfrentando uma epidemia no Brasil. Rio de Janeiro (RJ): Jorge Zahar; 1997. p.43-68.

25. Vieira-da-Silva L, Pinell P. The genesis of collective health in Brazil. Sociol Health Illn. 2014;36(3):432-46. DOI:10.1111/1467-9566.12069

Funding: Fundação de Amparo à Pesquisa do Estado da Bahia (FAPESB - 020/2010 - Research Program for SUS: Shared Health Care Management PPSUS/2010 - MS/CNPq/FAPESB/SESAB).

Authors' Contribution: Creation and planning of the study: SGB, LMVS. Interviews and document analysis: SGB. Analysis and interpretation of the data: SGB, LMVS. Drafting of the manuscript: SGB. Critical review of the manuscript: LMVS. All authors approved the final draft of the article.

Conflict of interest: The authors declare no conflict of interest. 


\section{RSP \\ Revista de \\ Saúde Pública}

http://www.rsp.fsp.usp.br/

In the Portuguese version of the article: "The genesis of the AIDS policy and AIDS Space in Brazil (1981-1989)" published in the "Revista de Saúde Pública", volume 50 (2016), number 43, DOI:10.1590/S1518-8787.2016050005801, the following references should be added at the end of section References:

24. Teixeira PR. Políticas públicas em AIDS. In: Parker R, organizador. Políticas, instituições e AIDS: enfrentando uma epidemia no Brasil. Rio de Janeiro (RJ): Jorge Zahar; 1997. p.43-68.

25. Vieira-da-Silva L, Pinell P. The genesis of collective health in Brazil. Sociol Health IIIn. 2014;36(3):432-46. DOI:10.1111/1467-9566.12069 


\section{RSP \\ Revista de \\ Saúde Pública}

http://www.rsp.fsp.usp.br/

In the article: "The genesis of the AIDS policy and AIDS Space in Brazil (1981-1989)" published in the "Revista de Saúde Pública", 2016;50:43, DOI: http://dx.doi.org/10.1590/ s1518-8787.2016050005801; on page 8, 7th paragraph.

\section{Where it reads:}

“azithromycin (AZT)".

\section{It should read:}

“zidovudine (AZT)”. 